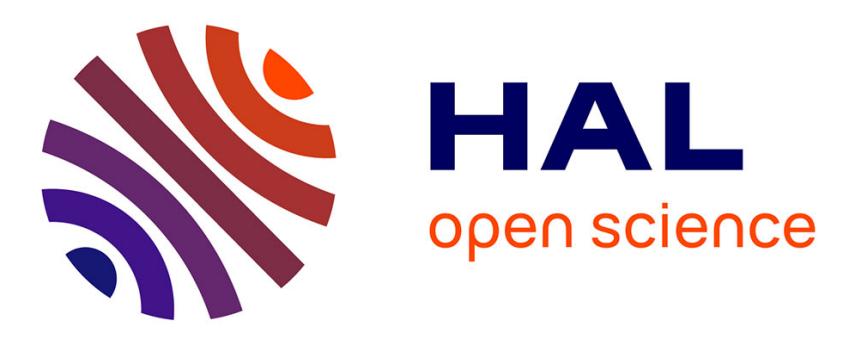

\title{
Zirconia-spinel composites. Part I: synthesis of powders and dense materials
}

Olivier Quénard, Christophe Laurent, Alain Peigney, Abel Rousset

\section{To cite this version:}

Olivier Quénard, Christophe Laurent, Alain Peigney, Abel Rousset. Zirconia-spinel composites. Part I: synthesis of powders and dense materials. Materials Research Bulletin, 2000, vol. 35, pp. 1967-1977. 10.1016/S0025-5408(00)00410-4 . hal-00950063

\section{HAL Id: hal-00950063 https://hal.science/hal-00950063}

Submitted on 20 Feb 2014

HAL is a multi-disciplinary open access archive for the deposit and dissemination of scientific research documents, whether they are published or not. The documents may come from teaching and research institutions in France or abroad, or from public or private research centers.
L'archive ouverte pluridisciplinaire HAL, est destinée au dépôt et à la diffusion de documents scientifiques de niveau recherche, publiés ou non, émanant des établissements d'enseignement et de recherche français ou étrangers, des laboratoires publics ou privés. 


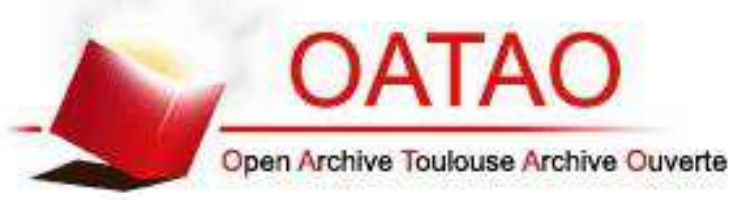

Open Archive Toulouse Archive Ouverte (OATAO)

OATAO is an open access repository that collects the work of Toulouse researchers and makes it freely available over the web where possible.

This is an author-deposited version published in: http://oatao.univ-toulouse.fr/ Eprints ID: 10980

Identification number: DOI : 10.1016/S0025-5408(00)00410-4

Official URL: http://dx.doi.org/10.1016/S0025-5408(00)00410-4

\section{To cite this version:}

Quénard, Olivier and Laurent, Christophe and Peigney, Alain and Rousset, Abel Zirconia-spinel composites. Part I: synthesis of powders and dense materials. (2000) Materials Research Bulletin, vol. 35 (n 12). pp. 1967-1977. ISSN 00255408

Any correspondence concerning this service should be sent to the repository administrator: staff-oatao@inp-toulouse.fr 


\title{
Zirconia-spinel composites. Part I: synthesis of powders and dense materials
}

\author{
O. Quénard, Ch. Laurent*, A. Peigney, A. Rousset \\ CIRIMAT, UMR CNRS 5085/LCMIE, Centre Interuniversitaire de Recherche et d'Ingénierie des Matériaux, \\ Université Paul-Sabatier, 31062 Toulouse Cedex 4, France
}

\begin{abstract}
$\mathrm{MgAl}_{2} \mathrm{O}_{4}$ and $\mathrm{x}$ wt $\% \mathrm{ZrO}_{2}-\mathrm{MgAl}_{2} \mathrm{O}_{4}(1 \leq \mathrm{x} \leq 30)$ composite powders were prepared by the urea combustion route. The powders were further ground by either ball milling or attrition to refine the grain size. Zirconia was found solely in the tetragonal form. Dense materials were prepared by hot pressing. The spinel matrix grains were submicronic in size. The $\mathrm{ZrO}_{2}$ particles were homogeneously dispersed at the grain junctions of the matrix, and their average size increased from less than $0.20 \mu \mathrm{m}$ to ca. $0.45 \mu \mathrm{m}$ with increasing content of $\mathrm{ZrO}_{2}$. The formation of monoclinic $\mathrm{ZrO}_{2}$ particles proceeded accordingly, being easier in materials with a finer matrix grain size (ex-attrition). () 2001 Elsevier Science Ltd. All rights reserved.
\end{abstract}

Keywords: A. Oxides; A. Composites; B. Chemical synthesis; C. Electron microscopy; D. Microstructure

\section{Introduction}

The spinel $\mathrm{MgAl}_{2} \mathrm{O}_{4}$ has many interesting properties, including a high melting point, a low thermal expansion coefficient, low dielectric losses, and excellent resistance to acid and alkali, but its poor mechanical properties at room temperature limit its field of applications. A well-known method for the enhancement of the mechanical properties of ceramics is the dispersion of micrometric $\mathrm{ZrO}_{2}$ particles as a discrete second phase. However, most studies have dealt with $\mathrm{ZrO}_{2}-\mathrm{Al}_{2} \mathrm{O}_{3}$ composites (see Wang and Stevens [1] for a review), and only

\footnotetext{
* Corresponding author. Tel.: +33-561-55-61-22; Fax: +33-561-55-1-63.

E-mail address: laurent@ iris.ups-tlse.fr (Ch. Laurent).
} 
a few with $\mathrm{ZrO}_{2}-\mathrm{MgAl}_{2} \mathrm{O}_{4}$ composites [2-6]. The synthesis and microstructure of the latter materials are reviewed in the following.

Claussen and Rühle [2] prepared $25 \mathrm{wt} \% \mathrm{ZrO}_{2}-\mathrm{MgAl}_{2} \mathrm{O}_{4}$ composites by mixing $\mathrm{Al}_{2} \mathrm{O}_{3}$ and $\mathrm{MgO}$ powders with zirconium acetate, which decomposes to form $\mathrm{ZrO}_{2}$ during a heat treatment. Both the metastable tetragonal form $\left(\mathrm{t}-\mathrm{ZrO}_{2}\right)$ and the monoclinic form $\left(\mathrm{m}-\mathrm{ZrO}_{2}\right)$ of $\mathrm{ZrO}_{2}$ are detected after either hot pressing $\left(60 \% \mathrm{t}-\mathrm{ZrO}_{2}\right)$ or conventional sintering $\left(20 \% \mathrm{t}-\mathrm{ZrO}_{2}\right)$. Fujita et al. [3] prepared powders of spinel and of a 24 wt $\% \mathrm{ZrO}_{2}$-spinel composite by the powder mixing and alkoxides routes. In these materials, the spinel was alumina rich $\left(\mathrm{MgO}: \mathrm{Al}_{2} \mathrm{O}_{3}=3: 4\right)$. Dense specimens (relative density $\geq 95 \%$ ) were prepared by conventional sintering or hot pressing. The matrix grain size was close to $2 \mu \mathrm{m}$ in the sintered (ex-alkoxide) spinel and $\mathrm{ZrO}_{2}-$ spinel materials, and the average size of the $\mathrm{ZrO}_{2}$ particles was $0.5 \mu \mathrm{m}$. For the hot-pressed (expowder mixing) materials, the matrix grain size was close to $4-5 \mu \mathrm{m}$ in the spinel, and much smaller $(1.2 \mu \mathrm{m})$ in the composite. The proportion of $\mathrm{t}-\mathrm{ZrO}_{2}$ in the as-prepared dense materials was higher than $95 \%$, but it was much lower in the polished specimens (ca. 80\%). Oudjedi et al. [4] prepared dense $\mathrm{ZrO}_{2}-\mathrm{MgAl}_{2} \mathrm{O}_{4}$ composites (relative density $\geq 98 \%$ ) by conventional sintering of composite powders synthesized by the sol-gel method. They reported that $\mathrm{ZrO}_{2}$ favors sinterability and that the dense materials exhibit a very fine microstructure without exaggerated spinel grain growth. The $\mathrm{ZrO}_{2}$ particles and the $\mathrm{MgAl}_{2} \mathrm{O}_{4}$ grains were found to be in the 0.05-0.2 $\mu \mathrm{m}$ and $0.5-1 \mu \mathrm{m}$ size ranges, respectively. The $\mathrm{ZrO}_{2}$ particles were finely dispersed, and they were found entirely as $\mathrm{t}-\mathrm{ZrO}_{2}$, up to a total content of $\mathrm{ZrO}_{2}$ equal to $20 \mathrm{wt} \%$. Suzuki et al. [5] prepared composite powders of yttria-stabilized $\mathrm{ZrO}_{2}$ and $\mathrm{MgAl}_{2} \mathrm{O}_{4}$ by double nozzle ultrasonic spray pyrolysis. The particles were in the form of needles and spheres, some of which were hollow. The average diameter of the spherical $\mathrm{MgAl}_{2} \mathrm{O}_{4}$ and $\mathrm{ZrO}_{2}$ particles was 0.47 and $0.60 \mu \mathrm{m}$, respectively, but the size distribution was fairly large. The powders were wet milled and cold-isostatically pressed prior to sintering in air $\left(1700^{\circ} \mathrm{C}, 10 \mathrm{~h}\right)$. They claimed that a powder containing $6.64 \mathrm{~mol} \%$ yttria-stabilized $\mathrm{ZrO}_{2}$ has an excellent sinterability because the relative density is equal to $97.6 \%$, while a composite with a higher $\mathrm{ZrO}_{2}$ content $(24.49 \mathrm{~mol} \%)$ presents a much poorer sinterability. Upon sintering, the $\mathrm{ZrO}_{2}$ particles and the $\mathrm{MgAl}_{2} \mathrm{O}_{4}$ grains grow to sizes close to 3 and $20 \mu \mathrm{m}$, respectively, and consequently, some $\mathrm{ZrO}_{2}$ particles are entrapped in the spinel grains. Hyun and Song [6] prepared a $20 \mathrm{wt} \% \mathrm{ZrO}_{2}$-spinel composite powder by the emulsion-hot kerosene route. The sintered material (relative density $=97.8 \%$ ) consisted of a spinel matrix (grain size $=1.5-2 \mu \mathrm{m})$ containing $1-2 \mu \mathrm{m}$ cubic $\mathrm{ZrO}{ }_{2}\left(\mathrm{c}-\mathrm{ZrO}_{2}\right)$ agglomerates made up of much smaller primary grains.

The aims of this work were, first, to investigate the direct synthesis of $\mathrm{ZrO}_{2}-\mathrm{MgAl}_{2} \mathrm{O}_{4}$ composite powders with different $\mathrm{ZrO}_{2}$ contents, and second, to study the microstructure of dense specimens prepared by hot pressing. The combustion synthesis method [7] was chosen because it is simple and cost effective, and allows large quantities of powders to be produced quickly. In particular, $\mathrm{MgAl}_{2} \mathrm{O}_{4}$ [7,8] and $\mathrm{ZrO}_{2}-\mathrm{Al}_{2} \mathrm{O}_{3}$ composite powders [7] have been prepared by this method. The mechanical properties of the present $\mathrm{ZrO}_{2}-\mathrm{MgAl}_{2} \mathrm{O}_{4}$ composites are reported in a companion paper [9]. 


\section{Experimental}

$\mathrm{MgAl}_{2} \mathrm{O}_{4}$ and $\mathrm{x}$ wt $\% \mathrm{ZrO}_{2}-\mathrm{MgAl}_{2} \mathrm{O}_{4}(\mathrm{x}=1,5,10,20$, and 30) composite powders were prepared by the combustion route. The appropriate amounts of the desired metal nitrates were mixed in stoichiometric proportions with urea and dissolved in the minimum amount of water in a Pyrex vessel. The quantities were calculated so that a combustion batch yields about $6 \mathrm{~g}$ of oxide powder. The stoichiometric composition of the redox mixtures was calculated using the total oxidizing and reducing valency of the metal nitrates (oxidizer) and urea (fuel), which serves as numerical coefficient for the stoichiometric balance, so that the equivalence ratio is equal to unity [7]. The vessel containing the solution was inserted into a furnace preheated to $600^{\circ} \mathrm{C}$. The solution immediately started to boil and undergo dehydration. The decomposition of the metal nitrates was accompanied by a large release of gases (oxides of nitrogen and ammonia). The obtained paste frothed and formed a foam, which swelled and then ignited. A white flame occurred with the production of a material that swelled to the capacity of the Pyrex vessel. The total combustion process took place in less than 5 min.

Elemental analysis confirmed that the combustion products contained the desired proportions of magnesium, aluminum, and zirconium, the observed differences being smaller than the standard deviation of the analysis method ( $\pm 2 \%$ ). For each composition, the so-obtained powders were separated into two parts, which were ground using different methods. Some specimens were ball milled for $1 \mathrm{~h}$ in ethanol using zirconia balls and vessel. These powders will hereafter be denoted as BM0, BM1, BM5, BM10, BM20, and BM30, the number reflecting the $\mathrm{ZrO}_{2}$ weight percentage. The other powders were attrition milled for 40 min in an aqueous solution of dispersant (Duramax D-3005) using alumina balls smaller than $2 \mathrm{~mm}$ in diameter and a rotor and a vessel both made of nylon. A calcination in air $\left(500^{\circ} \mathrm{C}, 15 \mathrm{~min}\right)$ was performed to burn the carbon contamination originating from nylon erosion and from the dispersant. These powders will be denoted as A0, A1, ..., A30 in the following sections.

The $\mathrm{BM}$ and A powders were uniaxially hot pressed in graphite dies at $1500^{\circ} \mathrm{C}$ in a primary vacuum. The hot-pressed specimens $(20 \mathrm{~mm}$ in diameter and $2 \mathrm{~mm}$ thick) were ground with diamond suspensions to a finish finer than $6 \mu \mathrm{m}$, and a final polish was made using "colloidal" silica $(0.05 \mu \mathrm{m})$. Relative densities were calculated from the mass and dimensions of the hot-pressed composites. For the sake of brevity, the compounds issued from the hot pressing of ball-milled and attrited powders are denoted as BM and A specimens, respectively.

Phase detection and identification was performed with X-ray diffraction (XRD) pattern analysis $(\mathrm{Co} \mathrm{K} \alpha, \lambda=0.17902 \mathrm{~nm})$ on powders and silica-polished dense specimens. The relative amounts of tetragonal and monoclinic zirconia $\left(\mathrm{t}-\mathrm{ZrO}_{2}\right.$ and $\mathrm{m}-\mathrm{ZrO}_{2}$, respectively) were calculated from the XRD patterns using the Garvie-Nicholson equation [10]. The powders and dense specimens were also studied by scanning and transmission electron microscopy (SEM and TEM, respectively). To reveal the grain boundaries of the matrix, the dense materials were etched in boiling $\mathrm{H}_{3} \mathrm{PO}_{4}\left(12 \mathrm{~mol} \mathrm{liter}^{-1}\right)$. The average size of the spinel grains was obtained by the linear intercept method. 


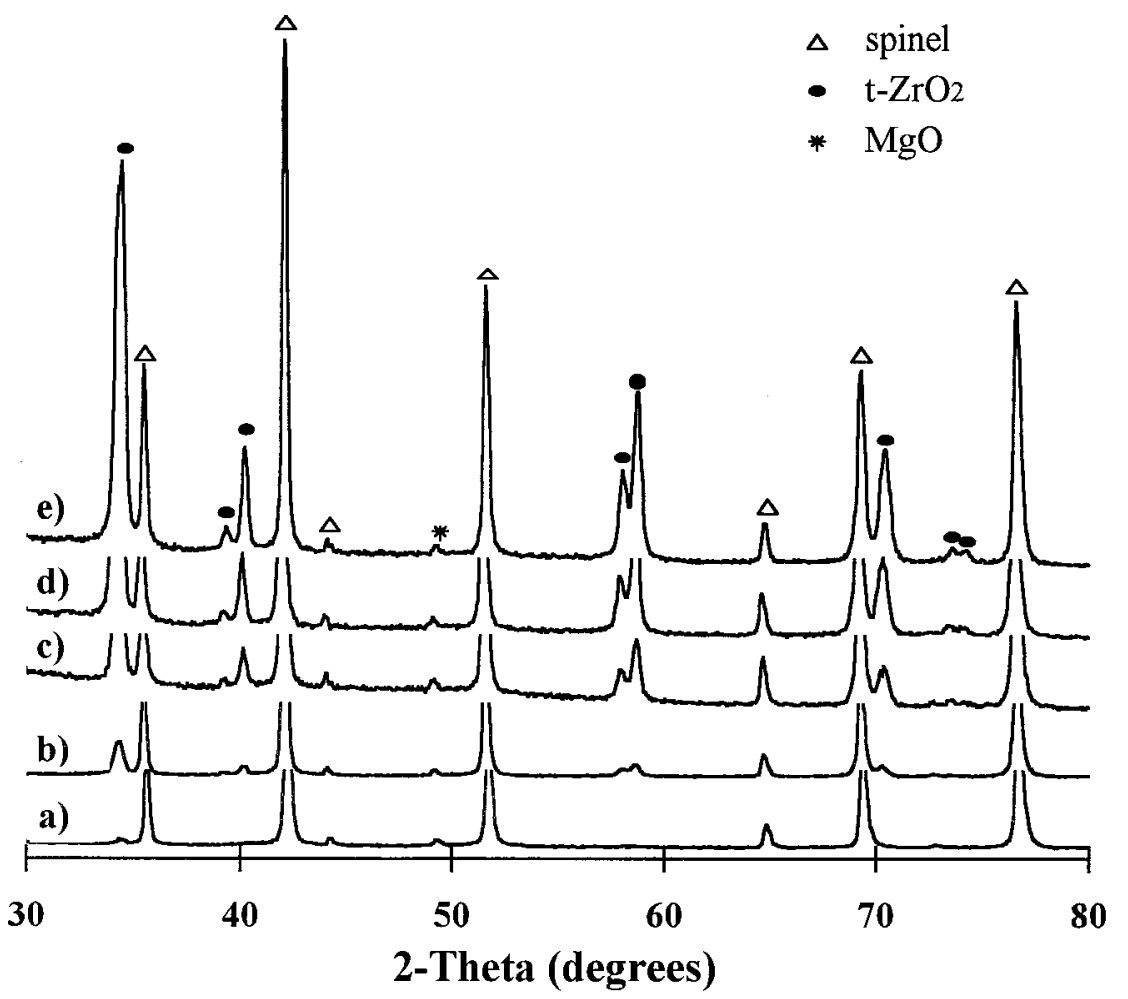

Fig. 1. XRD patterns of the ball-milled $\mathrm{ZrO}_{2}-\mathrm{MgAl}_{2} \mathrm{O}_{4}$ composites (a) BM1, (b) BM5, (c) BM10, (d) BM20, and (e) BM30.

\section{Results and discussion}

\subsection{Powders}

Analysis of the XRD patterns of the BM powders (Fig. 1) shows, in addition to the spinel and $\mathrm{ZrO}_{2}$ phases, the presence of a small amount of $\mathrm{MgO}$. The relative intensity of the (200) $\mathrm{MgO}$ peak is similar whatever the $\mathrm{ZrO}_{2}$ content. It was previously shown [8] that the spinel prepared by the present method is not the stoichiometric $\mathrm{MgAl}_{2} \mathrm{O}_{4}$ compound, but, rather, a slightly nonstoichiometric $\mathrm{Mg}_{1-3 \mathrm{x}} \square_{\mathrm{x}} \mathrm{Al}_{2+2 \mathrm{x}} \mathrm{O}_{4}$ ( $\square$ : vacancy) spinel with $\mathrm{x}$ less than 0.02 . The lattice parameter of the present spinel phase is $0.8083 \mathrm{~nm}$, showing no deviation, compared with that reported for stoichiometric $\mathrm{MgAl}_{2} \mathrm{O}_{4}$ [11]. Only the tetragonal form of $\mathrm{ZrO}_{2}$ is detected in the XRD patterns whatever the $\mathrm{ZrO}_{2}$ content. The same result was obtained from XRD patterns of the powders prior to any grinding (not shown). These results could indicate that the combustion route in the present experimental conditions produces $\mathrm{ZrO}_{2}$ particles small enough to allow the suppression of the tetragonal-to-monoclinic ( $\mathrm{t} \rightarrow$ $\mathrm{m})$ phase transformation during the rapid cooling from the flame temperature to the furnace temperature. This is supported by comparing with the work of Kingsley and Patil [7] reporting the combustion synthesis of $\mathrm{ZrO}_{2}-\mathrm{Al}_{2} \mathrm{O}_{3}$ composite powders, in which all the $\mathrm{ZrO}_{2}$ 

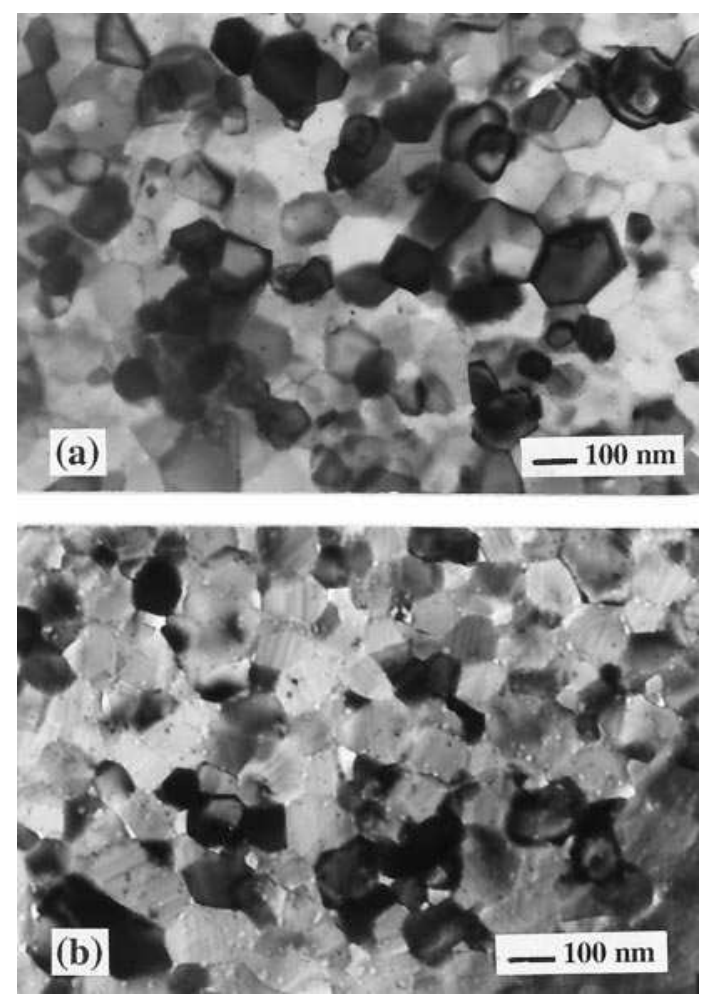

Fig. 2. TEM images of the ball-milled powders (a) BM0 and (b) BM5.

particles are tetragonal and have a size close to $30 \mathrm{~nm}$. Similar features are observed in the XRD patterns of the A powders, but a small proportion of $\alpha-\mathrm{Al}_{2} \mathrm{O}_{3}$ is also detected, resulting from the erosion of the balls used for attrition. The relative intensity of the most intense $\alpha-\mathrm{Al}_{2} \mathrm{O}_{3}$ peak is similar for all A powders, and elemental analysis indicates that the amount of $\alpha-\mathrm{Al}_{2} \mathrm{O}_{3}$ is close to $5 \mathrm{wt} \%$ (ca. $6 \mathrm{~mol} \%$ ).

SEM observations of the as-prepared (unground) $\mathrm{ZrO}_{2}-\mathrm{MgAl}_{2} \mathrm{O}_{4}$ powders reveals a microstructure similar to that previously observed for pure $\mathrm{MgAl}_{2} \mathrm{O}_{4}$ [8]. The grains are platelet-like and their surface shows holes resulting from the escaping of the gases during the combustion process. For powder BM0, the agglomerate size distribution measured by sedimentation granulometry in ethanol is fairly large $(1-18 \mu \mathrm{m})$ with a flat peak close to 6 $\mu \mathrm{m}$. For powder A0, the agglomerate size distribution is narrow $(0.5-3.5 \mu \mathrm{m})$ with a peak close to $1.5 \mu \mathrm{m}$. These results are in agreement with the SEM observations conducted on the $\mathrm{BM}$ and A powders, respectively. TEM examinations of the $\mathrm{MgAl}_{2} \mathrm{O}_{4}$ powders revealed that the grains are made up of polyhedral crystallites, the size of which ranges between 20 and $200 \mathrm{~nm}$ (Fig. 2a). The $\mathrm{ZrO}_{2}-\mathrm{MgAl}_{2} \mathrm{O}_{4}$ composite powders appear to be very similar to the $\mathrm{MgAl}_{2} \mathrm{O}_{4}$ ones. Indeed, the $\mathrm{ZrO}_{2}$ particles appear as dark areas on the TEM images (Fig. 2b), and are not easily distinguished from the spinel crystallites, because some $\mathrm{MgAl}_{2} \mathrm{O}_{4}$ crystallites in the Bragg position can also appear as dark areas. In situ energy dispersive X-ray analysis is essential to discriminate between them. Owing to these difficulties, we did not 


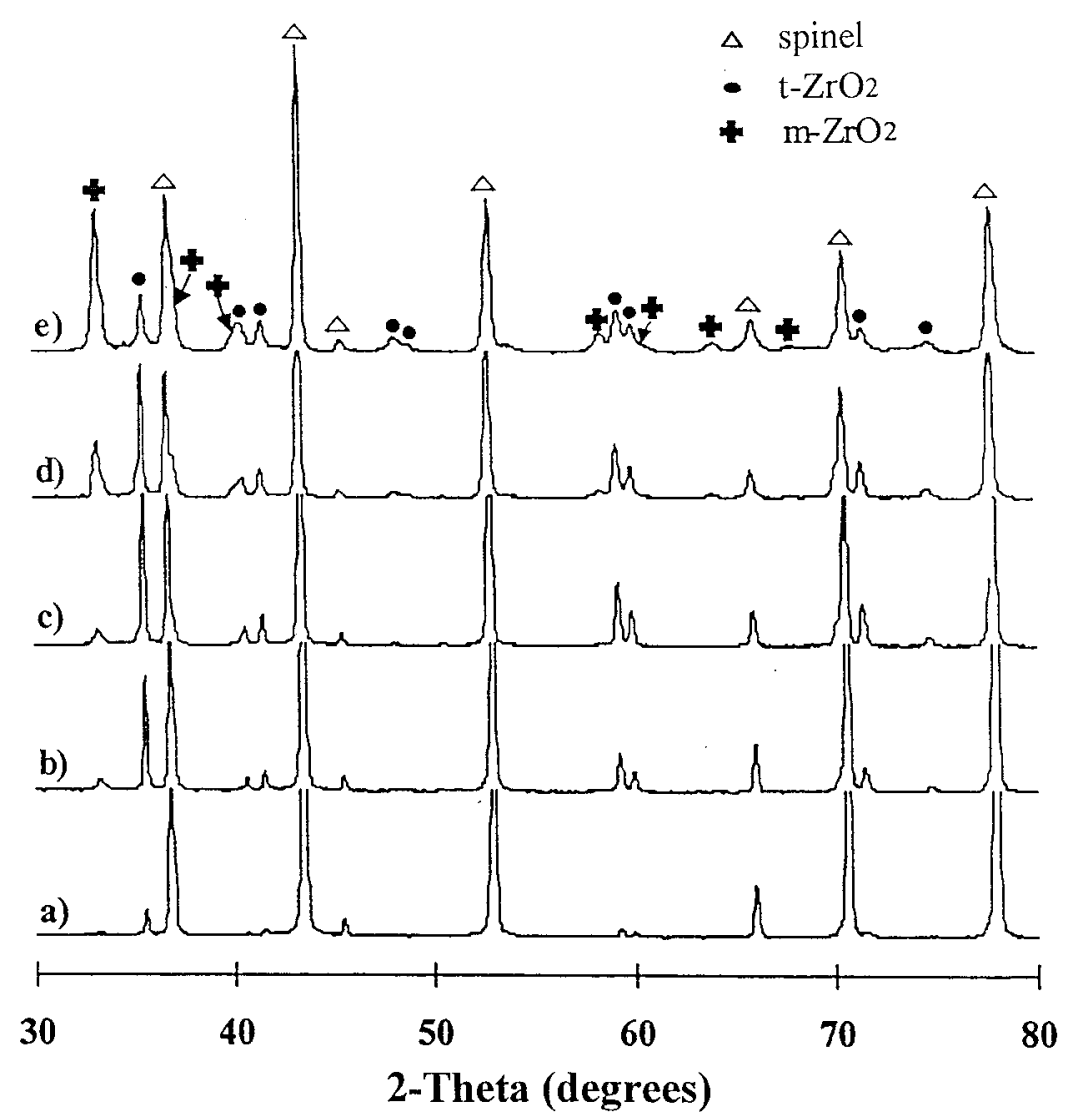

Fig. 3. XRD patterns of the hot-pressed $\mathrm{ZrO}_{2}-\mathrm{MgAl}_{2} \mathrm{O}_{4}$ composites (A specimens) (a) A1, (b) A5, (c) A10, (d) A20, and (e) A30.

attempt to evaluate the average size and size distribution of the $\mathrm{ZrO}_{2}$ particles in the powders. It seems that no $\mathrm{ZrO}_{2}$ particles are dispersed in the intragranular position in the matrix.

\subsection{Hot-pressed composites}

Analysis of the XRD patterns of the BM specimens reveals that the only detected phases are the spinel, $\mathrm{t}-\mathrm{ZrO}_{2}$, and $\mathrm{m}-\mathrm{ZrO}_{2}$. $\mathrm{MgO}$ is no longer present, indicating that the $\mathrm{Mg}^{2+}$ ions have reintegrated with the spinel lattice during hot pressing. Thus, the matrix of the $\mathrm{BM}$ dense specimens is the stoichiometric spinel. $\mathrm{Al}_{2} \mathrm{O}_{3}$ is not detected in the XRD patterns of the A compounds (Fig. 3), indicating that the $\mathrm{Al}^{3+}$ ions have diffused into the spinel lattice during hot pressing. The resulting oxide matrix is thus an aluminum-rich spinel, the formula of which is $\mathrm{Mg}_{1-3 \mathrm{y}} \square_{\mathrm{y}} \mathrm{Al}_{2+2 \mathrm{y}} \mathrm{O}_{4}$. According to the elemental analysis performed on the $\mathrm{A} 0$ powder (ca. $6 \mathrm{~mol} \%$ excess $\mathrm{Al}_{2} \mathrm{O}_{3}$ ), one can estimate that $\mathrm{y}$ is close to 0.03 , leading to the formula $\mathrm{Mg}_{0.91} \square_{0.03} \mathrm{Al}_{2.06} \mathrm{O}_{4}$. In contrast to what has been observed for the powders, both $\mathrm{t}-\mathrm{ZrO}{ }_{2}$ and $\mathrm{m}-\mathrm{ZrO}_{2}$ are present in the hot-pressed materials, except for BM1 and $\mathrm{A} 1$, in which only $\mathrm{t}-\mathrm{ZrO}_{2}$ was detected. The proportion of $\mathrm{t}-\mathrm{ZrO}_{2}$ (Table 1) slightly decreased to a 
Table 1

Some characteristics of the $\mathrm{ZrO}_{2}-\mathrm{MgAl}_{2} \mathrm{O}_{4}$ hot-pressed specimens

\begin{tabular}{llcll}
\hline Specimen $^{\mathrm{a}}$ & $\mathrm{d}_{\mathrm{r}}$ & $\mathrm{t}-\mathrm{ZrO}_{2}$ & $\varnothing_{\mathrm{s}}$ & $\varnothing_{\mathrm{z}}$ \\
\hline BM0 & 96.2 & - & 1.4 & $\mathrm{n}-\mathrm{m}^{\mathrm{b}}$ \\
BM1 & 96.5 & 100 & 0.8 & 0.19 \\
BM5 & 95.7 & 84 & 0.8 & 0.25 \\
BM10 & 98.3 & 89 & 0.8 & 0.36 \\
BM20 & 96.9 & 87 & 0.8 & 0.44 \\
BM30 & 96.7 & 48 & 0.3 & - \\
A0 & 95.5 & 100 & 0.3 & $\mathrm{n}-\mathrm{m}$ \\
A1 & 95.7 & 88 & 0.3 & 0.35 \\
A5 & 96.6 & 89 & $\mathrm{n}-\mathrm{m}$ & 0.37 \\
A10 & 95.8 & 60 & 0.2 & 0.42 \\
A20 & 96.4 & 19 & $\mathrm{n}-\mathrm{m}$ & 0.44 \\
A30 & 94.8 & & \\
\hline
\end{tabular}

$\mathrm{d}_{\mathrm{r}}$ : relative density; $\mathrm{t}-\mathrm{ZrO}_{2}$ : proportion $(\%)$ of tetragonal zirconia with respect to the total amount of $\mathrm{ZrO}_{2} ; \varnothing_{\mathrm{s}}$ and $\varnothing_{\mathrm{z}}$ : average size $(\mu \mathrm{m})$ of the spinel grains and of the $\mathrm{ZrO}_{2}$ particles, respectively.

${ }^{\mathrm{a}} \mathrm{BM}$ and $\mathrm{A}$ denote specimens issued from hot-pressing of ball-milled and attrited powders, respectively, and the number indicates the $\mathrm{ZrO}_{2}$ content in wt $\%$.

${ }^{\mathrm{b}} \mathrm{n}-\mathrm{m}$ : not measured.

value close to $85 \%$ for BM5, BM10, and BM20, and sharply decreased upon further addition of $\mathrm{ZrO}_{2}$ (48\% for BM30). A similar evolution is observed for the A composites, but it is noteworthy that the sharp decrease of the $\mathrm{t}-\mathrm{ZrO}_{2}$ proportion takes place for a lower $\mathrm{ZrO}_{2}$ content $(60 \%$ for $\mathrm{A} 20)$. The $\mathrm{m}-\mathrm{ZrO}_{2}$ particles are formed owing to the $\mathrm{t} \rightarrow \mathrm{m}$ phase transformation occurring for the larger $\mathrm{ZrO}_{2}$ particles upon cooling from the hot-pressing temperature. Thus, the increasing proportion of $\mathrm{m}-\mathrm{ZrO}_{2}$ upon the increase in the total amount of $\mathrm{ZrO}_{2}$ reflects the growth of the $\mathrm{ZrO}_{2}$ particles. Their gathering at the matrix grain junctions is easier when these grains are smaller (A specimens). The hypothesis that polishing could have provoked the $\mathrm{t} \rightarrow \mathrm{m}$ phase transformation of $\mathrm{ZrO}_{2}$ particles located at the surface of the materials was ruled out, because it has been checked that the proportion of $\mathrm{m}-\mathrm{ZrO}_{2}$ is similar in the unground, $6 \mu \mathrm{m}$ ground, and silica-polished specimens.

The main characteristics of the hot-pressed materials are presented in Table 1. The relative density $\left(d_{r}\right)$ ranges between 94.8 and 98.3. In contrast to other results [4,5], which indicate that the densification of $\mathrm{MgAl}_{2} \mathrm{O}_{4}$ is favored by the addition of $\mathrm{ZrO}_{2}$, there is no correlation between $\mathrm{d}_{\mathrm{r}}$ and the total $\mathrm{ZrO}_{2}$ content. However, the present specimens were hot pressed, giving similar relative densities for the spinels and the $\mathrm{ZrO}_{2}-\mathrm{MgAl}_{2} \mathrm{O}_{4}$ composites $\left(\mathrm{d}_{\mathrm{r}}>\right.$ $94.8 \%)$, whereas the spinel sintered in air without applying a charge [4,5] were poorly densified $\left(d_{r}<85 \%\right)$, the more so when it is aluminum-rich [12]. Except for BM10, which has a higher $\mathrm{d}_{\mathrm{r}}$ than any other present specimen $(98.3 \%)$, there are no significant differences in $\mathrm{d}_{\mathrm{r}}$ between the $\mathrm{BM}$ and A materials.

The SEM images of the etched surfaces (Fig. 4) show that the spinel grain size $\left(\varnothing_{\mathrm{s}}\right.$ in Table 1) is larger in the BM composites (ca. $0.8 \mu \mathrm{m})$ than in the A specimen $(0.3 \mu \mathrm{m})$. This reflects the difference in grain size in the corresponding powders. These images also confirm that the $\mathrm{ZrO}_{2}$ particles are located at the grain boundaries or grain junctions of the matrix (Fig. 4a). The average grain size of the spinel grains $\left(\varnothing_{\mathrm{s}}\right)$ is smaller for the BM composites 

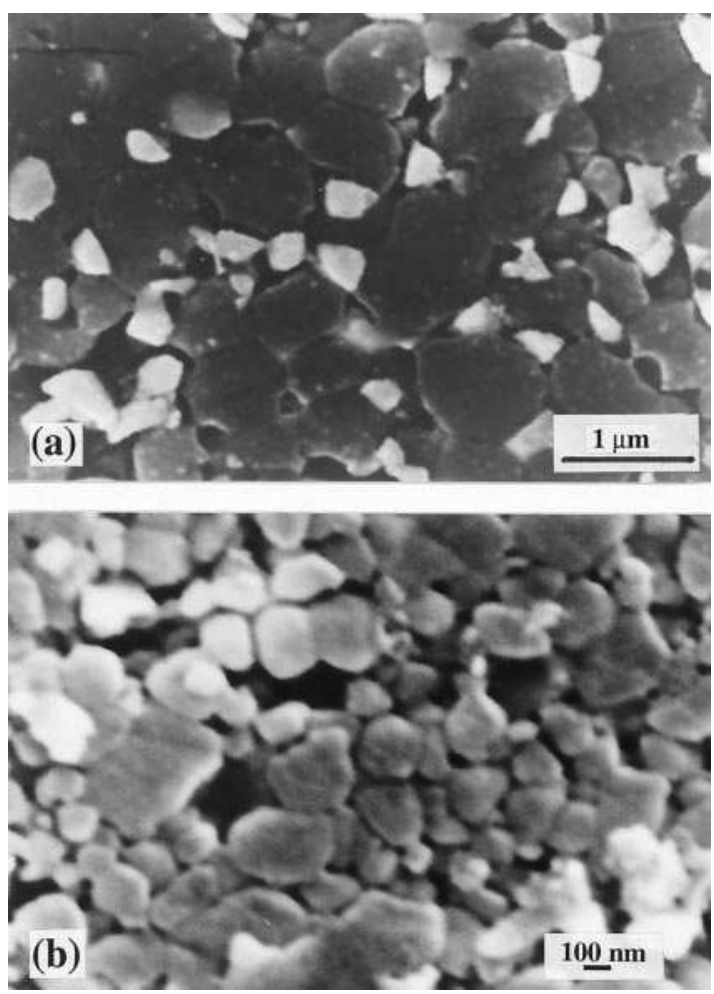

Fig. 4. SEM images of the etched surface of some hot-pressed $\mathrm{ZrO}_{2}-\mathrm{MgAl}_{2} \mathrm{O}_{4}$ composites (a) BM20, and (b) A5.

(ca. $0.8 \mu \mathrm{m})$ than for BM0 $(1.4 \mu \mathrm{m})$, showing that the presence of $\mathrm{ZrO}_{2}$ particles inhibits the growth of the matrix grains upon hot pressing. On the contrary, the presence of $\mathrm{ZrO}_{2}$ particles has no or very little influence on the average size of the spinel grains $(0.2-0.3 \mu \mathrm{m})$ for the A specimens. One may note that it has been difficult to reveal the grain boundaries of the A specimens. A treatment in $\mathrm{H}_{3} \mathrm{PO}_{4}$ that is too long leads to the destruction of the smaller matrix grains $(<0.1 \mu \mathrm{m})$, whereas a treatment that is too short does not enable one to reveal the grain boundaries. Numerous tests performed on A10 using different durations failed and thus $\varnothing_{\mathrm{s}}$ has not been measured for this composite.

The SEM backscattered images (BEI) of the polished surface of the composites (Fig. 5) show the $\mathrm{ZrO}_{2}$ particles (appearing as white areas on a dark background) dispersed at the grain boundaries and grain junctions of the spinel matrix. Very few $\mathrm{ZrO}_{2}$ particles are observed in BM1. In BM5 (Fig. 5a) and BM10, the dispersion of the $\mathrm{ZrO}_{2}$ particles is homogeneous and their shape is quite isotropic. Similar results have been obtained for A5 (Fig. 5d) and A10 specimens. For BM20 and BM30 (Fig. 5b and c), it is observed that some gathering at spinel grain boundaries produces $\mathrm{ZrO}_{2}$ particles with anisotropic shapes. In contrast, more $\mathrm{ZrO}_{2}$ particles have kept an isotropic shape in $\mathrm{A} 20$ and A30 (Fig. 5e and f), but they are larger than in BM20. The size distribution of the $\mathrm{ZrO}_{2}$ particles in the $\mathrm{BM}$ and A composites (Fig. 6) was obtained from the measurement of at least 300 particles on the SEM negatives. The average size $\left(\varnothing_{\mathrm{z}}\right)$ of the $\mathrm{ZrO}_{2}$ particles increases from 0.18 to $0.44 \mu \mathrm{m}$ in the BM materials and from 0.35 to $0.45 \mu \mathrm{m}$ in the A composites with an increasing total 

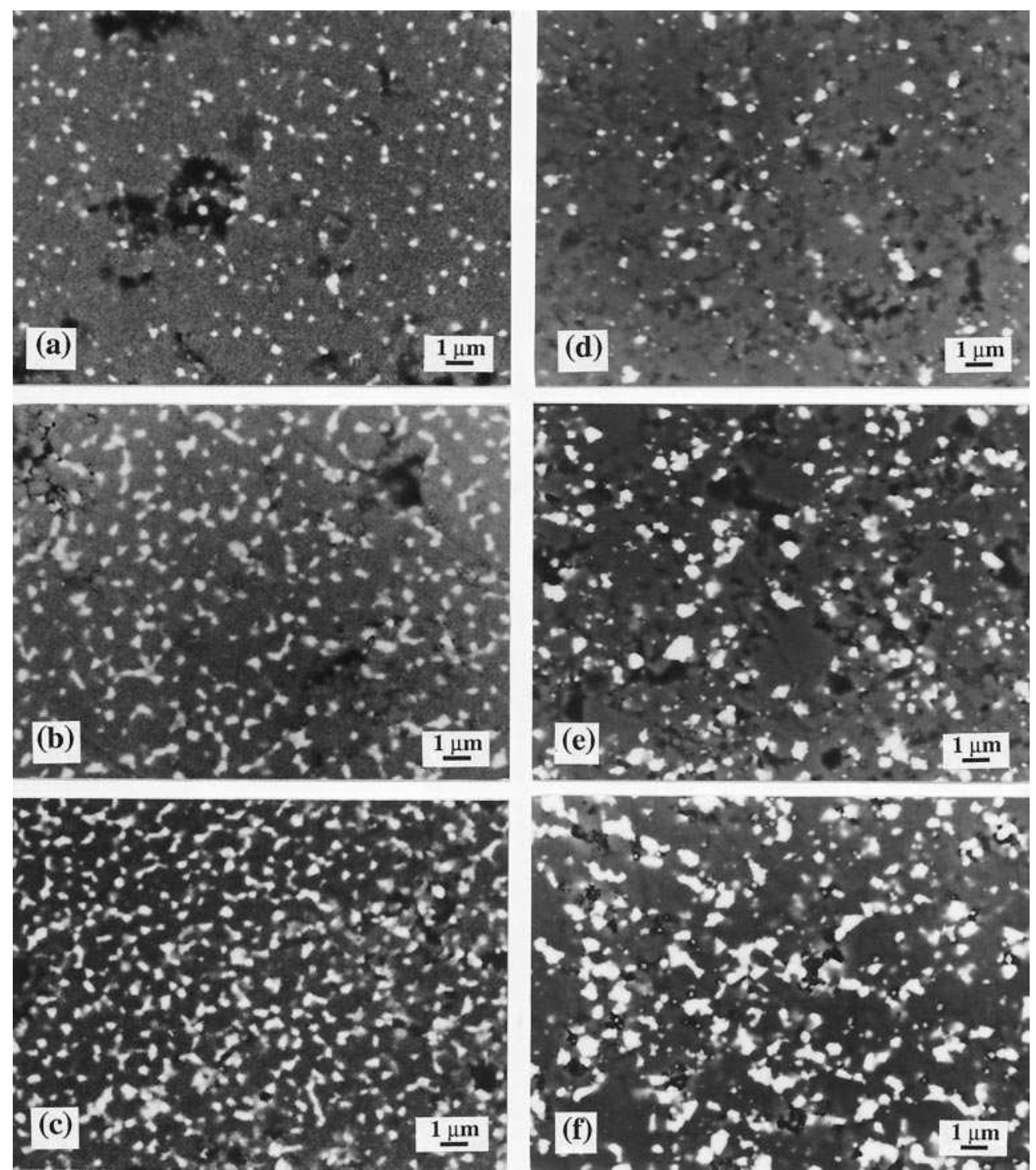

Fig. 5. SEM back-scattered images (BEI) of the polished surface of the hot-pressed $\mathrm{ZrO}_{2}-\mathrm{MgAl}_{2} \mathrm{O}_{4}$ composites (a) BM5, (b) BM20, (c) BM30, (d) A5, (e) A20, and (f) A30.

amount of $\mathrm{ZrO}_{2}$ from 5 to $30 \mathrm{wt} \%$ (Table 1). For a given $\mathrm{ZrO}_{2}$ content, the size relative to the maximum of the distribution profile is similar in both cases, but $\varnothing_{\mathrm{z}}$ is higher for the A composites. Indeed, a shoulder appears on the high-size side of the distribution profile, indicating the presence of larger $\mathrm{ZrO}_{2}$ particles $(>0.5 \mu \mathrm{m})$, which results in a higher average particle size. The presence of such large particles arises from the gathering of some $\mathrm{ZrO}_{2}$ particles at spinel grain junctions. Indeed, this phenomenon is more pronounced in the A composites than in the BM composites, because the spinel grains are much smaller $\varnothing_{\mathrm{s}}$ in Table 1) in the former. These results are in good qualitative agreement with the evolution of 

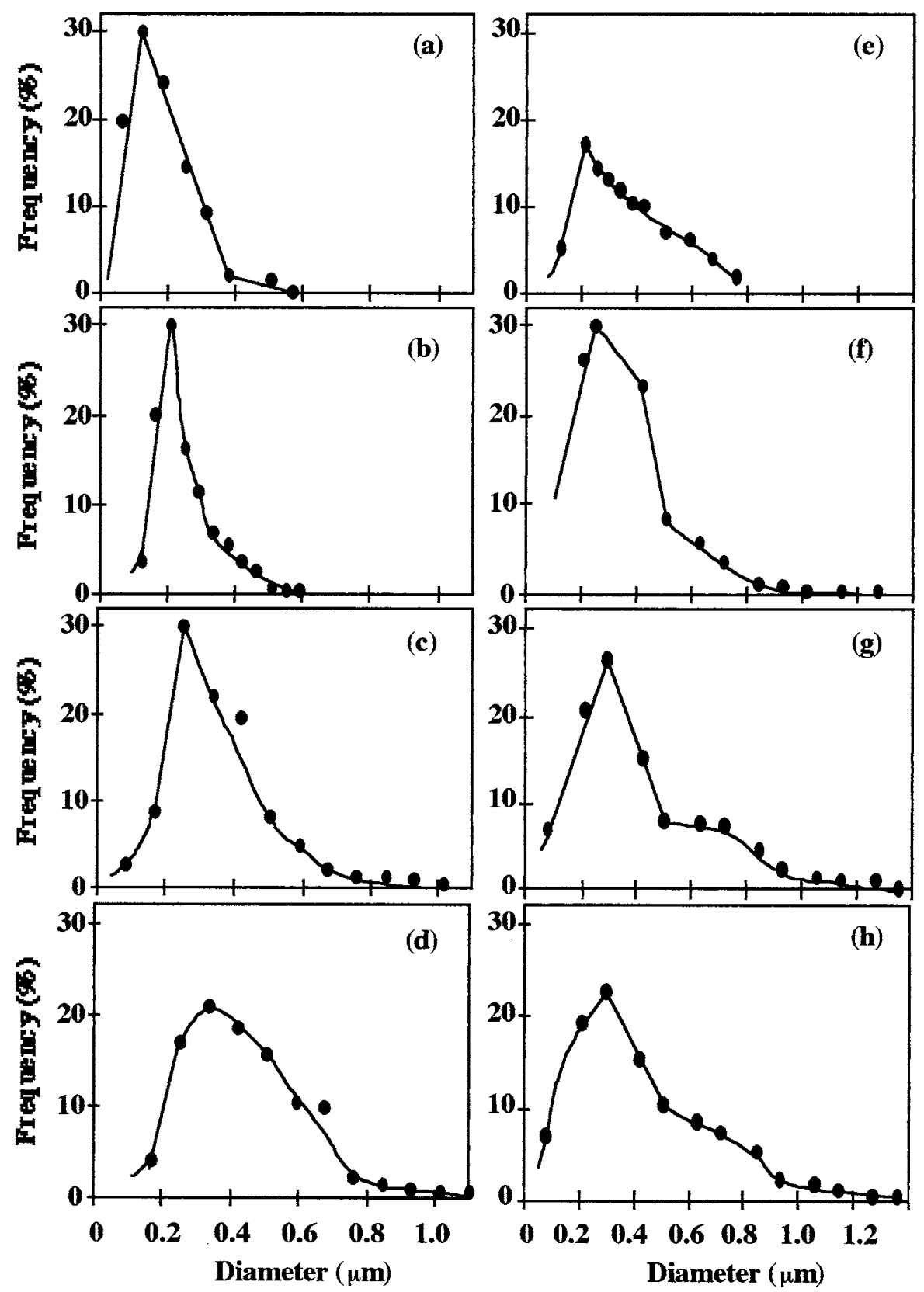

Fig. 6. Size distribution (in number) of the $\mathrm{ZrO}_{2}$ particles in the hot-pressed $\mathrm{ZrO}_{2}-\mathrm{MgAl}_{2} \mathrm{O}_{4}$ composites (a) BM5, (b) BM10, (c) BM20, (d) BM30, (e) A5, (f) A10, (g) A20, and (h) A30. The solid lines are guides for the eye.

the proportion of $\mathrm{m}-\mathrm{ZrO}_{2}$ as deduced from the $\mathrm{X}$-ray diagrams. SEM images of polished materials at a lower magnification also showed some differences in the residual porosity between $\mathrm{BM}$ and $\mathrm{A}$ specimens. In the BM ones, the pores are generally larger, less numerous, and often with more isotropic shapes than those of the A specimens. Indeed, in the latter 
composites, the anisotropic pores are located between agglomerates, which, being too hard, are probably insufficiently crushed upon hot pressing.

\section{Conclusions}

It has been shown that $\mathrm{MgAl}_{2} \mathrm{O}_{4}$ and $\mathrm{x}$ wt\% $\mathrm{ZrO}_{2}-\mathrm{MgAl}_{2} \mathrm{O}_{4}(1 \leq \mathrm{x} \leq 30)$ composite powders can be readily prepared by the urea combustion route. This method is cost effective and suitable for scaling up. The powders are further ground by either ball milling or attrition to refine the grain size. The $\mathrm{ZrO}_{2}$ particles are small enough to retain the tetragonal form. In dense materials prepared by hot pressing, the spinel matrix grains are submicronic in size. The $\mathrm{ZrO}_{2}$ particles are homogeneously dispersed at the grain junctions of the matrix and their average size increases from less than $0.20 \mu \mathrm{m}$ to ca. $0.45 \mu \mathrm{m}$ upon increasing the content of $\mathrm{ZrO}_{2}$. The formation of monoclinic $\mathrm{ZrO}_{2}$ particles $(0.2-0.45 \mu \mathrm{m})$ proceeds accordingly, being easier in the materials with the finer matrix grain size (ex-attrition). Such $\mathrm{ZrO}_{2}-$ $\mathrm{MgAl}_{2} \mathrm{O}_{4}$ composites may be of interest for superplastic forming, and present improved mechanical characteristics compared to pure $\mathrm{MgAl}_{2} \mathrm{O}_{4}$.

\section{References}

[1] J. Wang, R. Stevens, J Mater Sci 24 (1989) 3421.

[2] N. Claussen, M. Rühle, in: Advanced Ceramics, Vol. 3: Science and Technology of Zirconia, American Ceramics Society, Westerville, OH, 1981, p. 137.

[3] M. Fujita, H. Yoshimatsu, A. Osaka, Y. Miura, J Ceram Soc Jpn Int Ed 103 (1994) 81.

[4] Z. Oudjedi, R. Guinebretiere, A. Dauger, S. Marchant, B. Soulestin, in: A. Bellosi (Ed.), Fourth Euro Ceramics, Grupo Editoriale Faenza Editrice S.p.A., 1995, p. 53.

[5] T. Suzuki, K. Itatani, M. Aizawa, F.S. Howell, A. Kishioka, J Eur Ceram Soc 16 (1996) 1171.

[6] S.H. Hyun, W.S. Song, J Mater Sci 31 (1996) 2457.

[7] J.J. Kingsley, K.C. Patil, Mater Lett 6 (1988) 427.

[8] O. Quénard, Ch. Laurent, M. Brieu, A. Rousset, Nanostruct Mater 7 (1996) 497.

[9] O. Quénard, A. Peigney, Ch. Laurent, A. Rousset, Mater Res Bull 35 (12) (2000) in press.

[10] R.C. Garvie, P.S. Nicholson, J Am Ceram Soc 55 (1972) 303.

[11] H.E. Swanson, R.K. Fuyat, Natl Bur Stand Circ 539 (1953) 30.

[12] W.T. Bakker, J.G. Lindsay, Am Ceram Soc Bull 46 (1967) 1094. 